\title{
Asiantuntijuus kokemuksena
}

\author{
ULPUKKA ISOPAHKALA-BOURET
}

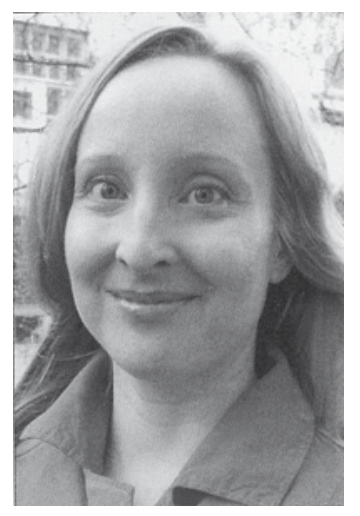

\begin{abstract}
Millaisista elementeistä kokemus asiantuntijuudesta rakentuu? Asiantuntijuuteen kokemuksellisena ilmiönä kuuluu asiaankuuluva tietämys, tilannesidonnainen kyky toimia sekä luottamuksen ja varmuuden tunne. Nämä voisivat kuvata toimijuuden kokemuksellisia elementtejä yleisemminkin. Oleellista on kuitenkin se, millaista tietämystä oletetaan olevan, millaista kykyä toimia edellytetään ja millaista luottamuksen ja varmuuden tunnetta tarvitaan kussakin sosiaalisesti määrittyvässä tilanteessa, jotta kokemus voidaan nimetä asiantuntijuudeksi.
\end{abstract}

\begin{abstract}
A siantuntijuudella voidaan tarkoittaa professionaalisuutta, joka perustuu tieteelliseen ja ammatilliseen tietoon, sekä alakohtaisiin tiedonmuodostuksen käytänteisiin (vrt. Eräsaari 2002; 2003). Perinteisesti asiantuntijat ovat toimineet erikoistuneiden instituutioiden puitteissa, antaneet luotettavina pidettyjä lausuntoja, osallistuneet päätöksentekoon ja harjoittaneet itsenäisesti ammattiaan alansa traditioiden ohjaamina (emt.). Nykyään he joutuvat kuitenkin kohtaamaan ainutkertaisia, epävarmoja ja monimutkaisia tilanteita, jotka eivät ole ainoastaan teknisesti haasteellisia, vaan sisältävät myös ristiriitaisia arvoja ja enemmän kuin yhden tavan määrittää päätöksenteon reunaehdot (Schön 1986). Asiantuntijuus onkin tällöin jotain sellaista, joka auttaa suunnistamaan, kyseenalaistamaan, ottamaan tuntumaa tai vain tuomaan helpotusta tukalaan tilanteeseen, mutta ei tarjoa valmiita reseptejä (Eräsaari 2002, 26). Lisäksi asiantuntijuuteen liittyy angloamerikkalaisen vaikutuksen (vrt. eksperttiys) myötä myös oletus taitavasta suorituksesta (Tynjälä 2004, 176; IsopahkalaBouret 2005, 45).
\end{abstract}

Kasvatustieteellistä asiantuntijuustutkimusta on kiinnostanut erityisesti asiantuntijuuden kehittyminen koulutuksen ja työelämän konteksteissa. Sitä on vahvasti suunnannut Bereiterin ja Scardamalian (1993) käsitys asiantuntijuudesta asteittain etenevänä ongelmanratkaisuprosessina, jossa oleellista on työskentely oman osaamisen äärira- joilla, tavoitteiden asettaminen yhä haasteellisemmalle tasolle ja sitä kautta tapahtuva itsensä ylittäminen. Asiantuntijuus määrittyy näin selkeästi toimintatapana, ei ominaisuutena (Tynjälä 1999). Viime aikoina tutkimus on painottunut tällaisen toimintatavan yhteisöllistä luonnetta. Kiinnostus on kohdentunut verkostomaisiin toimintasysteemeihin ja -prosesseihin, niin sanottuun kollektiiviseen asiantuntijuuteen ja sen kehittämiseen (Launis \& Engeström 1999; Hakkarainen, Palonen, Paavola \& Lehtinen 2004; Parvinen 2006).

Asiantuntijuutta voi tarkastella myös kokemuksellisena ilmiönä. Tämän artikkelin tarkoituksena on tutkia, kuinka asiantuntijayhteisöihin osallistuvat toimijat jäsentävät kokemuksiaan asiantuntijuudesta (tai sen puutteesta). Tavoitteena on mallintaa aineistolähtöisesti, millaisista osatekijöistä kokemus asiantuntijuudesta rakentuu. Tämä ei tarkoita sitä, että asiantuntijuus palautetaan yksilölähtöiseksi, muista toimijoista ja toimintakontekstista irralliseksi, yksilön ”pään sisällä” olevaksi tietorakenteeksi ja informaation prosessoinniksi (esim. Glaser \& Chi 1998). Sen sijaan asiantuntijuuden kollektiivinen luonne otetaan huomioon käsitteellistettäessä sitä, millä perusteella asiantuntijat itse kokevat toimintansa asiantuntijuudeksi.

Kokemus asiantuntijuudesta peilautuu usein tilanteisiin, joissa asiantuntijamainen toimintatapa ei ole ollut syystä tai toisesta mahdollista. Näihin tilanteisiin liittyy kamppailua sen suhteen, mitä 
ylipäätään pidetään asiantuntijuutena. Asiantuntijuuden määrittely on valtaan kietoutunut ilmiö. Valtaa ei tässä tarkastella asiantuntija-maallikkoasetelmasta käsin, vaan niiden käytänteiden kautta, joilla luodaan käsitystä siitä, mitä asiantuntijuus on ja ketkä voivat perustellusti kutsua itseään asiantuntijoiksi. Asiantuntijuudeksi nimeäminen antaa toiminnalle, ratkaisuille, lausunnoille ja näkemyksille aivan erityisen painoarvon. Se oikeuttaa tietynlaiseen auktoriteettiin. Asiantuntijuus ilmenee kuitenkin eri tavoin ylikansallisella, kansallisella, yritys- ja työyhteisötasolla (Reunanen 1996, 5), eikä ole itsestään selvää, kenelle tuo auktoriteetti tulisi kulloinkin myöntää ja millä perusteella. Niinpä tässä artikkelissa asiantuntijuuden kokemusta tarkasteltaessa pohditaan myös asiantuntijuuden määrittelyyn liittyvää neuvottelua ja vallankäyttöä.

\section{Näkökulma kokemuksellisuuden tarkasteluun}

Ymmärrys asiantuntijuuden kollektiivisesta luonteesta tarjoaa puitteet lähestyä asiantuntijuutta kokemuksellisena ilmiönä. Kokemus asiantuntijuudesta rakentuu vuorovaikutteisesti, yhteisöllisten suhteiden kautta, jossain tietyssä historiallisessa ja sosiaalisessa kontekstissa (vrt. Lave \& Wenger 1991, "communities of practice"). Kokemus edellyttää osallistumista ja muilta saatua sosiaalista tunnustusta. Käytännössä sosiaalisen tunnustuksen saaminen tapahtuu usein niin, että ihmiseltä tullaan pyytämään neuvoa ja häntä pyydetään selittämään, miksi asia on niin tai näin (Hakkarainen, Palonen \& Paavola 2002, 456). Tällainen tunnustus saa hänet ottamaan älyllistä vastuuta tietystä aihealueesta, syventämään omaa osaamistaan ja näin ollen pikkuhiljaa kokemaan itsensä asiantuntijaksi (emt.). Kokemusta asiantuntijuudesta vahvistaa edelleen yhteisölliset mukaanottamisen käytännöt, kuten päätöksentekoon osallistaminen ja vastuullisten tehtävien antaminen.

Sosiaalisen tunnustuksen saaminen omalle asiantuntijuudelle edellyttää suostumista kontekstin asettamien asiantuntijamaisen toimintatavan ehtoihin. Vain toimimalla tiettyjen kulttuurisesti määrittyvien käytänteiden mukaisesti voi tulla tunnistetuksi ja tunnustetuksi (eng. recognized) tietynlaisena, tässä tapauksessa asiantuntijana (vrt. diskurssianalyyttinen teoria; esim. Gee 2005). Kulttuuriset merkityksenannot täten raamittavat sitä, mitä ja miten kussakin yhteydessä kuuluu sanoa ja tehdä toimiakseen kuten asiantuntijan kuuluu. Tällä on puolestaan vaikutusta siihen, millaisia kokemuksia nimetään asiantuntijuudeksi. Tässä mielessä kokemus asiantuntijuudesta on alisteinen kulttuurisille merkityksenannoille. Toki asiantuntijayhteisöihin osallistuvat toimijat ovat itse osaltaan luomassa näitä toimintansa ja kokemustensa reunaehtoja.

Kokemus asiantuntijuudesta edellyttää siis tietyssä määrin olemassa olevaan kontektisidonnaiseen asiantuntijarooliin (tai -positioon) asettumista. Tällainen itsensä paikantaminen tietyssä kontekstissa kulttuurisesti määrittyvän asiantuntijuuden sosiaaliseen kategoriaan tarkoittaa asiantuntijuuteen liitettyjen asioiden olettamista itseä kyseisessä roolissa kuvaaviksi ominaisuuksiksi (Ashforth 2001, 67). Joissain tapauksissa tähän liittyy myös oman asiantuntijuuden ja sen kehittymisen pohdintaa elämäkerrallisessa viitekehyksessä (mm. Kuinka olen tullut tähän tilanteeseen? Mikä on tämänhetkisen roolini suhde aikaisempaan työhistoriaani? Mihin tästä eteenpäin?)

Asiantuntijuuden kontekstisidonnaisuudesta seuraa, että ei ole yhtä oikeaa tapaa määrittää asiantuntijamaista toimintatapaa. Tämä puolestaan tarkoittaa sitä, että myös asiantuntijuuden kokeminen riippuu tilanteesta. Henkilö voi kokea olevansa asiantuntija tietyssä asiassa, tietyssä yhteisössä ja toisessa yhteydessä ei. Hän voi olla myös useassa eri kontekstissa asiantuntijana, mutta kussakin yhteydessä asiantuntijamainen toiminta voi edellyttää hieman erilaista tekemistä ja olemista. Asiantuntijuus ei siis ole henkilökohtainen ominaisuus tai pysyvä status. Monella asiantuntijayhteisöissä toimineella onkin kokemuksia sekä asiantuntijuudesta että sen puutteesta.

\section{Tutkimusmenetelmät}

Artikkeli perustuu väitöskirjatyöhön (IsopahkalaBouret, 2005), jonka lähtökohtana oli kokeneiden ammattilaisten omalle asiantuntijuudelleen antamien merkitysten tulkinta (vrt. Hytönen 2002). Tavoitteena oli sen selvittäminen, millä tavalla asiantuntijuutta tehdään ymmärrettäväksi ja mielekkääksi arkisten tarinoiden avulla työtehtävien muuttuessa. Tutkimuksessa sovellettiin narratiivista analyysia (mm. Mishler 1986; Riessman 1993), johon saatiin vaikutteita krittisestä elämänhistoriallisesta orientaatiosta (Goodson \& Sikes 2001). Yksittäiset tarinat kontekstualisoitiin tiettyyn historialliseen ja sosiaaliseen aikaan ja paikkaan. 
Keskityn tässä artikkelissa analysoimaan, millaisten sisällöllisten teemojen avulla tutkimukseen osallistuvat kiteyttävät kokemuksensa asiantuntijuudesta. En lähde määrittelemään asiantuntijuutta minkään ulkoa annetun kriteeristön perusteella. Sen sijaan kiinnitän analyyttisen huomion siihen, mistä osallistujat puhuvat, kun he puhuvat asiantuntijuudestaan. Tarkoituksena on lisäksi tarkastella kriittisesti, millaisin kulttuurisin ehdoin kokemus asiantuntijuudesta rakentuu.

Tutkimukseen osallistui yhdeksän eri tehtävissä toiminutta tietohallinnon ammattilaista eräästä suuresta, kansainvälisestä teknologia-alan yrityksestä. Mukana oli eri-ikäisiä, erilaisen koulutus- ja työhistorian omaavia miehiä ja naisia. Heitä yhdisti samankaltainen työtilanne eli he olivat kukin vaihtamassa työtehtäviään tutkimuksen aikana oman organisaationsa sisällä. Aineisto kerättiin vuoden 2002 aikana yksilöhaastatteluin ja ryhmäkeskusteluin. Haastattelut toteuttiin kahdeksan kuukauden välein ja niiden välissä osallistujat tapasivat toisiaan kahdessa eri pienryhmässä viisi kertaa. Tässä artikkelissa mukana olevat sitaatit ovat haastatteluaineistosta. Litteraatiota on pelkistetty eli non-verbaaliset ilmaisut, toistot, tauot ja haastattelijan välikommentit on jätetty pois. Sitaatteja on tiivistetty ja kohdat, joista on poistettu osioita, on merkitty pisteillä sulkujen sisällä (...). Haastateltavien nimet on muutettu.

Analyysimenetelmänä on narratiivisen aineiston temaattinen analyysi (Riessman 1993; 2008). Pääpaino on sisällöissä, ei niinkään kerronnan rakenteessa tai sen vuorovaikutteisuudessa, joita myös on analysoitu väitöskirjatyössä. Analyysiyksikkönä on yksittäisiä sanoja ja lauseita pidemmät kerronnalliset ja kuvailevat osiot, joissa tuodaan esiin kokemuksia asiantuntijuudesta. Artikkelin tulososiossa on mahdollista raportoida näistä vain katkelmia. Temaattisen analyysin tuloksena muodostetaan asiantuntijuuden kokemusta kuvaava malli.

\section{Tutkimustulokset}

Sosiaalisen tunnustuksen saaminen oli tässäkin tutkimuksessa asiantuntijuuden kokemuksen lähtökohta. Tunnustusta voitiin saada niin kollegoilta, esimieheltä kuin asiakkailtakin, kuten allaolevat esimerkit osoittavat.

Kyl niinku mun kollegat sano - osa niistä että jos kukaan muu ei tiedä, ni ne tulee mun luo kysymään. (Niko)
Oma pomo (...) kans kääntyy mun puoleen välillä näis isois kysymyksissä. (Niko)

Siis jos mä oon jossain palaverissa ja mult niinku pyydetään ex tempore selittämään asioita, ni kyllähän mä nyt siis pystyn selittämään. Ja (esimies) niinku kiittelee jälkeenpäin, että: "Voi, voi, kun sä nyt pätevästi niinku selitit." (...) ja sitte niinku tämä, et niinku tiimin jäsenet tulee kysyy multa juttuja,"koska sä oot se joka tietää!” (Kati)

(Jotkut asiakkaat sanovat:) "Ok, but you know what you are doing, so I let you do your thing." (Max)

Asiantuntijuuden kokemus määrittyi myös kyseistä kokemusta sisällöllisesti määrittävien osatekijöiden mukaan, jotka esittelen seuraavassa yksi kerrallaan. Tämän jälkeen vedän tuloksia yhteen teemojen pohjalta muodostuneen mallin avulla.

\section{Asiaankuuluva tietämys osana asiantuntijuuden kokemusta}

Asiantuntijuuden kokemus näytti edellyttävän jonkin tiedollisen ja taidollisen kokonaisuuden hallintaa (ks. alla) ja myös sitä, että pystyi nimeämään tähän liittyvän erityisen tietämyksensä jollain tavalla. Se edellytti näin ollen hyvää käsitystä omasta osaamisesta ja sen suhteesta muiden osaamiseen.

Pystyy niinku kertoo, et mikä on se juttu ja mitkä on nää ympäristöt. (Anne)

Ihan vaan nauttii siitä omasta osaamisestaan, (...kun) on jo se niin kun ympäristö hallinnassa. (...) Helpompi mieltää ne uudetkin asiat sitten, kun osaa sijoittaa ne omaan lokeroon siellä organisaatiossa ja muuten. (Sara)

Oma tietämys voitiin ilmaista asiakeskeisesti viittaamalla johonkin sovellukseen, tietokantaan, palveluun, järjestelmäympäristöön tai muuhun vastaavaan. Toisaalta omaa tietämystä voitiin määrittää irtautumalla asiakeskeisyydestä ja kuvailemalla omaa tapaa toimia, kuten seuraavissa esimerkeissä.

Mä haluun tietää tarpeeks jostain aiheesta ja mä tiedän, että se liittyy tiettyihin asioihin ja mä alan selvittää niitä asioita. (...) Mulle on tärkeetä se, että mun työtehtäväni tai mun osaamiseni tai muu, (et) mä ymmärrän mihin sillä on sidoksia. (Kati) 
Jos osaamista tarvitaan ja tulee joku ongelma (ja) sit jos vaihtoehto yks ei toimi, ni miten asian vois ratkaista, niin sitten keksii jonkun toisen konstin tehdä sen asian. (...) tiedon hakemista ja kysymistä muilta myös, et miten kannattaa tehdä. (Niko)

Asiantuntijuuden nähtiin näin edellyttävän asiakokonaisuuksien, asioiden välisten yhteyksien ja tiedon soveltamisen mahdollisuuksien ymmärtämistä. Tällöin asiantuntijuus määrittyi selkeästi toimintatapana, ei pysyvien asiasisältöjen hallintana.

Käsitys oman tietämyksen laadusta, oli kysymys sitten jonkin asiakokonaisuuden hallinnasta tai tietynlaisesta toimintatavasta, päivittyi tilanteisesti ja oman työhistorian myötä. Oman osaamisen taso pyrittiin varmistamaan jatkuvalla tietojen ja taitojen omatoimisella päivittämisellä ja tarvittaessa kouluttautumisella, kuten Henry alla ilmaisee.

On ollut se oman erikoisalan tuntemus tai oman alan tuntemus tai mä oon pyrkinyt, pyrin sitä hankkimaan. Joko olla sitä osaamista tai sitten hakea sitä. (Henry)

Usein oma tietämys ilmaistiin vertaamalla sitä johonkin ”toiseen”. Tällöin itsellä oleva tietämys esitettiin jollain lailla muita parempana (syvällisempänä, laajempana, ajantasaisempana, perustellumpana tai toimivampana) käsityksenä kulloinkin kyseessä olevasta asiasta. Asiantuntijuuteen liittyvää "paremmin tietämistä” ei välttämättä tuotu korostetusti ja suorasanaisesti esiin, mutta silti eroa tehtiin. Omaa tietämystä voitiin suhteuttaa vaikkapa omaan ei-teknisesti pätevään esimieheen, vasta-aloittaneisiin noviiseihin tai omaan osaamiseen aikaisemmassa työroolissa, kuten seuraavissa esimerkeissä tehdään.

Meil oli tossa pari vuotta sitten yks semmonen esimies. (...) Hän oli ollut jossain (järjestelmä) projekteissa mukana, muttei käytännössä ymmärtänyt (järjestelmästä) mitään. Ja sit kuitenkin tosi teknisiä juttuja käydään läpi. $\mathrm{Ni}$ kyl sen huomas, et ku niistä alettiin puhua, ni saman tien oli niinku yhteys poikki. (Timo)

Siin alussa se analysointivaihe oli aina hankala, ku (uusilla työntekijöillä) ei ollu niinku sitä kuvaa siitä, et miten se koko palvelu on rakennettu. Ni sit mun piti aina niinku käydä se niitten kanssa läpi ensin. Ja sitte ku ne ru- pes tekemään, ni niille tuli monta asiaa, mitä ne tuli aina kysymään. (Anne)

Toi edellinen tehtävä (teknisessä asiakaspalvelussa) oli, senkin rooli ulospäin oli niinku ehkä saman tapainen, mutta sä ehkä tiesit siitä (järjestelmästä) vähemmän. Et se on niinku, koska se rooli oli semmonen, et ne toiset oli tehnyt ohjelman ja sä olit vaan niinku asiakkaalle se näkyvä henkilö siinä, vaikka sä et itte kovin hyvin tienny sitä sisäistä ohjelmarakennetta esimerkiksi. (...) Nykyisessä työssä se on enemmän, et sä oikeesti tiedät sen, mistä jotku keskustelee. (Rami)

Asiantuntijuuden kokemuksen kannalta näytti siis olevan olennaista, että samanlaista kokonaisuuden hallintaa ei kenellä tahansa sellaisenaan ollut. Oma tietämys linkittyi toki omalla alalla yleisesti tunnettuun tietoperustaan ja alalla vakiintuneisiin ammatillisiin käytänteisiin. Siksi sitä ei vältämättä lähdettykään vertaamaan samalla alalla, samankaltaisissa asiantuntijatehtävissä toimiviin. Toisaalta taas alan tietoperusta oli erikoistumisen myötä pirstaloitunut niin, etteivät samalla alalla toimivat välttämättä jakaneet samaa tietopohjaa. Tämän lisäksi osa tutkimukseen osallistuneista toimi täysin uusilla "poikkitieteellisillä” osaamisalueilla, joilla ei ollut mitään vakiintunutta ja yhteisesti jaettua tietoperustaa. Lisäksi työhistoria, työkontekstin tuntemus ja tilannekohtaisesti määrittyvät työtehtävät muovasivat samankaltaisissa tehtävissä toimivillekin erityistä, muista erottuvaa tietämystä.

Tietämyksen oli oltava myös tilanteeseen ja tehtävään nähden asiaankuuluvaa ja oikeanlaista (eng. relevant). Se, mitä kuului milloinkin tietää, määrittyi asiayhteyden mukaan. Asiantuntijayhteisön jäsenet, kuten myös muut toimijat, organisaation johto, asiakkaat jne., olivat itse aktiivisesti määrittämässä sitä, millaisena tilanteet tuli nähdä ja mitä tietoa kulloinkin tuli soveltaa (vrt. Eräsaari 2003). Aika-ajoin syntyi myös erimielisyyksiä eri toimijoiden kesken. Tällöin oleellista ei ollut niinkään se, onko omaa tietämystään puolustava henkilö vai hänen asiantuntemustaan kriittisesti arvioivat tahot oikeassa, vaan se, miten neuvotteluprosessi ja sen lopputulema vaikuttivat yhteisössä vallitseviin käsityksiin koskien asiantuntijuutta. Tietämyksen oikeutuksesta neuvottelu on valtapeliä. Ja vain niille, joiden tietämys saa osakseen jaettua sosiaalista tunnustusta, mahdollistuu asiantuntijuuden kokeminen kyseisessä yhteisössä. Toki 
aina on mahdollista tulla tunnustetuksi asiantuntijana jossain toisessa yhteydessä saman de facto tietämyksen avulla.

\section{Tilannesidonnainen kyky toimia osana asiantuntijuuden kokemusta}

Asiantuntijuuden kokemukseen liittyi toisena elementtinä se, että pystyi vaikuttamaan asioihin ja edesauttamaan tärkeäksi näkemiensä päämäärien toteutumista, kuten seuraavissa lainauksissa ilmaistaan. Tällainen kyky toimia (eng. capacity to $a c t$ ) tarkoitti mahdollisuutta käyttää tietämystään kulloisenkin tilanteen ja tehtävän edellyttämällä tavalla. Se ei tässä viitannut niinkään taitoon tehdä asioita, vaan ennemminkin tietämyksen ja tilanteisten odotusten vastaavuuteen. Tällöin oli mahdollista vastata odotuksiin omalla toiminnalla tai muokata odotuksia oman parhaan tietämyksensä mukaisesti, (mikä puolestaan edellytti riittävää autonomiaa oman toiminnan suhteen).

Pystyy viemään niitä asioita sillee eteenpäin niinku ite haluaa tai oman tämmösen näkökantansa mukaisesti. (Anne)

Oli paljon hyviä keskusteluja ja sitten myös saatiin joitain asioita muutettua. (Niko)

Voidakseen vaikuttaa asioihin, oli omattava paikka toimijoiden verkostoissa. Oli päästävä osallistumaan sekä itse tekemiseen, että tekemistä koskeviin neuvotteluihin. Kyky toimia edellytti kuulluksi tulemista, kuten Sara ohessa tuo esiin.

Mut kutsutaan enemmän niihin kokouksiin mukaan ja toisaalta mun mielipidettä kuunnellaan vielä vähän enemmän. (Sara)

Asiantuntijuuden kokemukseen näytti vahvasti linkittyvän halu ja kyky kehittää sekä työn kohteena olevia asioita että omaa työtä. Asioista haluttiin kantaa vastuuta ja olla itse mukana toteuttamassa päätöksiä tai ainakin seuraamassa niiden toteuttamista.

Ei pelkästään oo päättämässä asioista, mut sit vastaa niistä. Et sehän on se taito: Osaa tehdä niin hyviä päätöksiä, että sitten se jatko sujuu hyvin. (Niko)

Kyky toimia edellytti myös riittäviä toimintaresurs- seja, kuten tehtäviin nähden riittävää työaikaa, sopivia työvälineitä ja mahdollisuutta palautua rauhassa suorituksesta. Se vaati myös suotuisia toiminnan reunaehtoja. Organisatoriset käytänteet, kuten työtä ohjaavat prosessit, säännöt ja työkalut sekä työnjaolliset ja työntekijöiden valintaan (rekrytointiin, nimittämisiin ja ylentämisiin) liittyvät seikat olivat oleellisia kyvylle toimia. Toiminnallisten prosessien ja niihin liittyvien ohjeistusten ja sääntöjen oli oltava riittävän selkeitä ja ennakoitavia, niiltä tuli myös voida edellyttää riittävää jatkuvuutta, jotta asiantuntijamainen toiminta mahdollistui. Tällaiset pysyvyyttä edustavat rakenteet kyseenalaistuivat ainakin väliaikaisesti muutosten ja yllättävien tilanteiden yhteydessä.

\section{Luottamuksen ja varmuuden tunne osana asiantuntijuuden kokemusta}

Asiantuntijuuden kokemukseen kuului myös "emotionaalinen” puoli. Tietämyksen ja kyvyn toimia lisäksi oli voitava luottaa omaan asiantuntijuuteensa ja tuntea olonsa varmaksi toimessaan asiantuntijatehtävissä. Aikaisemmissa tutkimuksissa tunteet on liitetty asiantuntijuuteen lähinnä itsesäätelyn käsitteen kautta (esim. Ruohotie 2000). Tällöin tunteiden rooli on ollut edesauttaa asiantuntijaksi kehittymistä ja hyvään asiantuntijasuoritukseen pääsemistä. Tunteita on tällöin pyritty ohjailemaan ja kontrolloimaan niin, että ne mahdollistavat kurinalaisen ja tavoitesuuntautuneen toiminnan. Asiantuntijuuden kokemuksessa luottamuksen ja varmuuden tunne (eng. confidence) osoittautui kuitenkin itseisarvoisen tärkeäksi.

Se miltä on tuntunu työssä, sehän kuitenkin vaikuttaa kaikkeen, minkälaista tulosta saa siinä työssä ja miten itse tuntee niinku voivansa tehdä sitä työtä. (Henry)

Luottamuksen ja varmuuden tunteella ei tässä viitata joissain popularistisissa elämäntapaoppaissa yleiseen käsitykseen itsevarmuudesta sisäisenä, hyvään itsetuntoon liittyvänä ominaisuutena. Hyvän itsetunnonhan ajatellaan yleisesti olevan sitä, että uskaltaa olla spontaani, luonnollinen oma itsensä ja tuntee olonsa miellyttäväksi pelokkuuden ja voimattomuuden sijaan. Kokemuksellisen asiantuntijuuden yhteydessä luottamuksen ja varmuuden tunnetta ei kuitenkaan tarkastella yksilöl- 
lisin käsittein. Se ei tässä yhteydessä viittaa myöskään verkostomaisessa asiantuntijatoiminnassa tärkeään toimijoiden keskinäiseen luottamukseen (eng. trust). Tosin näiden välillä voi nähdä yhteyden siinä mielessä, että muiden osoittama luottamus (vrt. sosiaalinen tunnustus) vahvistaa luottamusta omaan tietämykseen ja kykyyn toimia. Luottamuksen ja varmuuden tunne nähdäänkin kontekstisidonnaisena ja sosiaalisesti määräytyvänä.

Luottamuksen ja varmuuden tunteessa oli toisaalta kyse omien asiantuntijalausuntojen ja ratkaisujen pätevyydestä ja toimivuudesta. Esimerkiksi ohjelmointisuunnittelijana toiminut Rami käytti paljon aikaa ja energiaa luottamuksen ja varmuuden tunteen saavuttamiseen varmistamalla, että hän todella tiesi, mitä oli tekemässä ja että se, mitä hän oli tehnyt, oli virheetöntä ja toimivaa.

Siin on hirvee työ niinku yleensäkin kattoo, (...) ettei siin oo joku lyöny jotain (virheellisiä) merkkejä väliin (yhdessä tehtyyn koodiin). (Rami)

Toisaalta luottamuksen ja varmuuden tunteessa oli kysymys kokonaisnäkemyksen muodostumisesta, kuten seuraavassa Saran esimerkissä alla. Onhan vain osa tietämyksestä sellaista, että sen paikkaansapitävyys voidaan testata ja varmistaa. Useimmiten luottamuksen ja varmuuden tunne rakentui siis "faktojen" sijaan kokemuksen tuomalle perspektiiville ja oman toiminnan reunaehtojen tuntemiselle. Toisin sanoen se syntyi siitä, että tiesi myös, miksi asioita tehdään. Se liittyi työn päämäärien, relevanssin ja mielekkyyden kysymyksiin (vrt. Friman 2004). Luottamuksen ja varmuuden tunteessa on näin myös kyse eettis-moraalisten sitoumusten kautta syntyvästä vakuuttuneisuudesta, että tekee oikeita asioita.

Tavallaan se ei oo varmuutta, vaan se on tavallaan sellainen turvallisuuden tunne, että kaikki se mitä me tässä tehdään, ni kaikki se on sinne (projektin) hyväks ja sen päämäärän hyväks tehtyä työtä. (Sara)

\section{Kokemuksellisen asiantuntijuuden malli}

Kokemusta asiantuntijuudesta on edellä tarkasteltu kyseistä kokemusta rakentavien osatekijöi- den kautta. Aikaisemmat asiantuntijuuden osatekijöiden mallinnukset ovat olleet lähinnä kognitiivisesti orientoituneita. Niissä on jäsennelty yksilöllisen tiedonkäsittelyn ja ongelmanratkaisun edellyttämiä tiedollisia komponentteja (ks. Tynjälä 2004, 176). Asiantuntijuuden kokemusta tarkasteltaessa tietämys osoittautui kuitenkin vain yhdeksi tekijäksi, jonka rinnalla on muita yhtä tärkeitä elementtejä. Kokemuksellisen asiantuntijuuden mallin (ks. kaavio 1) mukaisesti kokemus asiantuntijuudesta edellyttää, a) että oma tietämys on asiaankuuluvaa suhteessa käsillä olevaan tehtävään tai tilanteeseen, b) että on kykenevä toimimaan oman tietämyksensä mukaan, ja c) että itsellä on luottamuksen ja varmuuden tunne suhteessa omaan tietämykseen ja kykyyn toimia.

Vedettäessä yhteen sitä, mitä tarkoitetaan asiaankuuluvalla tietämyksellä asiantuntijuuden kokemuksesta puhuttaessa, voidaan hyödyntää Tynjälän (2004, 177) esittämää asiantuntijuuden tiedollisten elementtien kolmijakoa. Asiantuntijuuteen sisältyy ensinnäkin muodollista, eksplisiittistä tietoa, kuten kullakin alalla yleisesti tunnettu perustieto (faktuaalinen tieto) sekä keskeisiä teorioita ja käsitteitä (käsitteellinen tieto). Toiseksi asiantuntijuuteen sisältyy kokemuksellista, implisiittistä tietoa, kuten sen tietäminen, miten asiat tehdään (proseduraalinen tieto/taito). Kolmanneksi

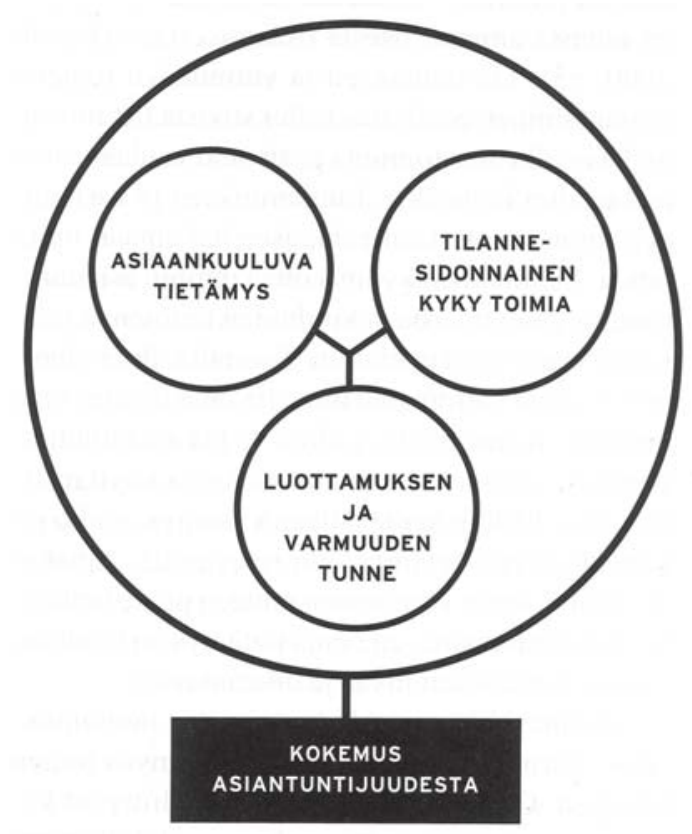

Kaavio 1: Osatekijät, joiden kautta kokemus asiantuntijuudesta rakentuu (vrt. Isopahkala-Bouret 2005, 157) 
tarvitaan myös itsesäätelytaitoa (metakognitiivinen, refleksiivinen tieto) eli oman toiminnan tietoista ohjausta ja oman ajattelun ottamista kriittisen tarkastelun kohteeksi. Käsitteellisesti on tarkoituksenmukaista tunnistaa nämä erilaiset tiedon lajit, vaikkakaan kokemuksen tasolla ne eivät välttämättä olleet erillisiä. Asiantuntijuuden kokemukseen puolestaan vaikutti voimakkaasti se, määrittyikö oma tietämys käsillä olevien tehtävien kannalta asiaankuuluvaksi ja oikeanlaiseksi.

Asiaankuuluvan tietämyksen ja kyvyn toimia välinen suhde on vuorovaikutteinen. Asiaankuuluvan tietämyksen omaaminen on edellytys asiantuntijamaiselle kyvylle toimia. Samanaikaisesti vasta toimintaan mukaan pääseminen usein mahdollistaa oppimisen ja uuden tiedon kehittelyn, joiden seurauksena syntyy tehtävien ja tilanteiden kannalta asiaankuuluvaa ja oikeanlaista tietämystä (vrt. asiantuntijuus osallistumisena ja tiedon luomisena, Hakkarainen et al. 2002). Toisaalta voidaan kärjistää ja kysyä, voiko tietämystä pitää asiaankuuluvana tehtävän ja tilanteen kannalta, jos sitä ei kykene hyödyntämään toiminnassa ja jos sen avulla ei pääse vaikuttamaan asioihin.

Asiaankuuluva tietämys sekä luottamuksen ja varmuuden tunne ovat samoin kiinteässä vuorovaikutuksessa keskenään. Ensinnäkin luottamuksen ja varmuuden tunne rakentuu tietämyksen varaan. Jo asiantuntijoiksi korkeakoulussa opiskelevat puhuvat varmuuden tunteesta osoituksena omasta ammatillisesta osaamisestaan (Kotila 2000, 65). Luottamuksen ja varmuuden tunteen saavuttaminen edellyttää refleksiivistä tietämistä, jonka avulla oma toiminta ja ajattelu voidaan ottaa tarkastelun kohteeksi. Luottamuksen ja varmuuden tunne puolestaan rohkaisee hakemaan uutta tietoa. Esimerkiksi kynnys ottaa muihin asiantuntijoihin yhteyttä asiaan kuuluvien tietojen ja neuvojen saamiseksi madaltuu. Toisaalta, ilman luottamuksen ja varmuuden tunnetta oma tietämys jää helposti ilmaisematta, jolloin se jää asiantuntijayhteisön kannalta näkymättömäksi ja käyttämättömäksi. Tällöin herää jälleen kysymys, voiko jakamatta jäävä tietämys olla relevanttia. Ainakin luottamuksen ja varmuuden tunteen puute heikentää kokemusta siitä, että oma tietämys on tilanteen kannalta asiaankuuluvaa ja oikeanlaista.

Tilannesidonnainen kyky toimia ja luottamuksen ja varmuuden tunne vaikuttavat myös toinen toisiinsa. Organisatoriset käytänteet liittyvät kykyyn toimia ja ne myös osaltaan mahdollistavat (tai estävät) luottamuksen ja varmuuden tunteen syntymisen. Luottamuksen ja varmuuden tunnetta ei siis voi lisätä pelkästään itsetuntemusta ja itsetuntoa vahvistamalla. Vain silloin kun asiantuntijatehtävissä toimivilla on riittävästi autonomiaa oman työnsä suhteen ja mahdollisuus vaikuttaa päätöksentekoon ja asioiden toimeenpanoon, vahvistuu myös luottamus omaan asiantuntijuuteen. Toisaalta toimintaan ja päätöksentekoon osallistuminen edellyttää luottamuksen ja varmuuden tunnetta. Luottaessaan tietämykseensä asiantuntijat ovat halukkaita ilmaisemaan näkemyksiään ja lähtemään mukaan yhteisöllisen tiedonrakentelun prosesseihin. Varmuus työn päämääristä ja tarkoituksesta lisäävät kykyä toimia.

\section{Pohdinta}

Tässä artikkelissa olen tarkastellut sitä, millaisista elementeistä kokemus asiantuntijuudesta rakentuu. Asiantuntijuuteen kokemuksellisena ilmiönä kuuluu kiinteästi kolme osa-aluetta: asiaankuuluva tietämys, tilannesidonnainen kyky toimia, sekä luottamuksen ja varmuuden tunne. Nämä käsitteet voisivat kuvata toimijuuden kokemuksellisia elementtejä yleisemminkin. Asiantuntijuuden ei nähdä tässä mielessä täysin poikkeavan muusta inhimillisestä toiminnasta. Oleellista on kuitenkin se, millaista tietämystä oletetaan, millaista kykyä toimia edellytetään ja millaista luottamuksen ja varmuuden tunnetta tarvitaan kussakin sosiaalisesti määrittyvässä tilanteessa, jotta kyseinen kokemus voidaan nimetä asiantuntijuudeksi.

Aikaisemmissa tutkimuksissa on korostettu asiantuntijuuden elementtien integroimisen tärkeyttä, mutta silloin on yleensä viitattu teoreettisen tietämisen linkittämiseen käytännöllisen tietämisen kanssa toimintaedellytysten lisäämiseksi (vrt. Tynjälä 2004). Kuten Hakkarainen ja kumppanit (2002) mainitsevat, reflektointi on avainasemassa tässä eri tiedollisten osa-alueiden yhdistämisessä. Tämä integrointityö on kuitenkin muutakin kuin älylliskognitiivinen haaste asiantuntijuuden kokemuksen saavuttamiseksi, kuten tässä artikkelissa olen osoittanut. Se ei ole myöskään puhtaasti individualistinen harjoitus.

Asiantuntijuuden kokeminen edellyttää, että pystyy vakuuttamaan itsensä ja muut sitä, että se mitä tietää ja osaa, on niin arvokasta, että sitä tulee pitää asiantuntijuutena (vrt. sosiaalinen tunnustus). Näin ollen tietämyksen, kyvyn toimia ja luottamuksen yhdistämiseen liittyy "performatiivinen” puoli: on osattava kerronnallisesti organi- 
soida aikaisemmat kokemukset ja nykyiset tilannekohtaiset edellytykset niin, että ne antavat riittävän perustelun omalle asiantuntijuudelle. Kokemus asiantuntijuudesta edellyttää onnistunutta neuvottelua vallitsevien asiantuntijuuskäsitysten kanssa ja vallalla olevien asiantuntijuutta määrittävien puheentapojen tietynasteista hyväksymistä. Esimerkiksi nykyinen käsitys asiantuntijamaisesta toimintatavasta edellyttää oikeanlaisen osaamisen lisäksi myönteistä asennetta oppimiseen, sopeutumiskykyä muuttuviin olosuhteisiin ja halua tarttua uusiin haasteisiin. Toisin sanoen se edellyttää kerrontaa omasta kehittymisestä, oman alan seuraamisesta, uusien tietojen ja taitojen opettelemisesta ja eteenpäin menevästä urasta (Filander 2000; Isopahkala-Bouret 2005). Toisaalta Filander $(2000,172)$ on todennut, että ammattilaiset ovat usein oppineet useita erilaisia tapoja ilmaista asiantuntijuuttaan ja kykenevät vaihtamaan puheessaan yhdestä diskurssista toiseen, jopa saman keskustelun aikana.

Kokemus asiantuntijuudesta on aina kontekstisidonnaista ja niinpä jokainen uusi tilanne asettaa sen koetukselle. Kokemus asiantuntijuudesta voidaan mitätöidä vaikkapa kyseenalaistamalla henkilön tietämyksen merkitys käsillä olevan asian suhteen; luomalla olosuhteet, joiden puitteissa henkilö on kyvytön toimimaan asiantuntijamaisesti; tai murentamalla henkilön luottamuksen ja varmuuden tunne. Käytännössä tämä usein tarkoittaa pieniä ja suuria arkisia tekoja, kuten mielipiteen kuulematta jättämistä, hankkeiden käynnistämistä ilman mukaan pyytämistä, rahallisten resurssien epäämistä, yllättävää tavoitteiden uudelleen asettamista ja ristiriitaisen palautteen antamista, kuten tuli esille tämän tutkimuksen puitteissa.

Esimerkiksi monessa suomalaisessa yrityksessä ja julkisorganisaatioissa, (kuten myös siinä organisaatiossa, jossa tämä tutkimus toteutettiin), asiantuntijuutta on pyritty tekemään näkyväksi erilaisten osaamiskartoitusten avulla. Osaamista mittaavat standardit syntyvät usein totunnaisen ajattelun tuloksena, tiettyjä strategisia tavoitteita ajamaan, eikä niitä ole välttämättä mitenkään empiirisesti todennettu (Norris, 1991). Osaamiskartalle ja strategisille taitolistoille mukaan päässeet osaamisalueet ja niiden kuvaukset heijastelevat yleensä yrityksen johdon ja muiden vallassa olevien näkemystä siitä, mikä on asiaankuuluvaa ja oikeanlaista tietämystä. Näin ollen yhteisössä, jossa oma tietämys ei tule näkyväksi virallisissa osaa- misen kuvauksissa ja sitä kautta sosiaalisesti tunnustetuksi, kokemus asiantuntijuudesta ei ole mahdollista. Asiantuntijuuden kokemisen edellytykseksi nousee siis sellaisen tietämyksen omaaminen, jota valtaa pitävät arvostavat.

Johdon lisäksi asiakas on noussut yllättävän keskeiseen rooliin tietämyksen merkitystä arvioitaessa. Yksityisellä sektorillahan kaikki toiminta perustuu viimekädessä tuottavuuteen ja voiton tavoitteluun, joka ei ilman tyytyväisiä asiakkaita ole mahdollista. Tämän tutkimuksen puitteissa esimerkiksi tietojärjestelmien ja ohjelmistojen kehittämistyötä tehtiin projekteissa, joissa työn tilaaja esitti vaatimuksia sille, millaista teknologiaa tulee käyttää, mitä tulee saada aikaan ja mitä tarkoitusta varten. Myös järjestelmien ylläpitotehtävissä työskentelevien työtä ohjasivat asiakkaiden palvelupyynnöt. Tällöin asiantuntijuuden nähtiin ilmenevän sellaisessa tietämyksessä, jolla on mahdollista reagoida nopeasti eteen tuleviin asiakastarpeisiin ja toisaalta kehittää asiakasta parhaiten palvelevia kokonaisratkaisuja. Kiinnostavaa onkin pohtia, ohittaako asiakkaan tahto asiantuntijaarvion päätöksenteossa niissä tapauksissa, joissa tarvittavan tietämyksen laadusta syntyy erimielisyyksiä vai onko asiantuntijayhteisöllä mahdollisuutta asettaa myös tekemisen ehtoja. Nähdäänkö asiantuntijatieto vain hyödykkeenä, jonka tarkoituksena on palvella organisaation ja osakkeenomistajien etuja (vrt. Fenwick 2004) vai kulkeeko rinnalla asiantuntijayhteisön itsemäärittelyoikeus omaan tietämykseensä nähden?

Asiantuntijaorganisaatioissa ei aina myöskään ole itsestään selvää, kuka saa osallistua asioista käytävään keskusteluun ja keiden ääntä kuullaan päätöksiä tehtäessä. Se, että jollakulla voisi olla asiaan liittyvää oleellista tietämystä, ei automaattisesti ole avain mukaan pääsyyn asioita koskevaan päätöksentekoon. Esimerkiksi tämän tutkimuksen aineistossa kuvailtiin tilanteita, joissa oman vastuualueen asioista ei päässytkään itse päättämään, vaan "ei-asiantuntijat” tai hierarkkisesti "ylemmän tason” toimijat tekivät päätökset. Ulkopuolisena jää vaille asiaankuuluvaa tietoa, eikä pysty muodostamaan kokonaiskäsitystä asioista. Poissuljettuna ei varsinkaan voi omalla panoksellaan vaikuttaa asioiden saamaan suuntaan ja etenemiseen. Tällöin ei myöskään kokemus asiantuntijuudesta ole mahdollinen.

Monet seikat saattavat puolestaan horjuttaa luottamuksen ja varmuuden tunteen syntymistä ja täten estää asiantuntijuuden kokemisen. Epä- 
vakaat työolot, kuten jatkuvat organisatorisen uudistukset, kehityshankkeet ja toimenkuvan muutokset pitävät jatkuvassa epävarmuuden ja ennakoinnin tilassa ja täten estävät asiantuntijuuteen kiinteästi kuuluvan varmuuden tunteen kehittymisen. Myös huonosti organisoidut työn tekemisen puitteet heikensivät luottamuksen ja varmuuden tunnetta (kuten myös kykyä toimia). Muun muassa yhteistyökumppanien poikkeaminen yhdessä sovituista toimintatavoista ja yhteistyöhön tarvittavien työvälineiden käytöstä (esim. sooloilu ohjelmistokoodin versionhallinnassa), yhdessä sovittujen pelisääntöjen puuttuminen (esimerkiksi omaa työtä koskevia päätöksiä joutuu tekemään arvailujen varassa), johdon taholta luvattujen asioiden muuttuminen (esim. nimityksen peruuntuminen tai viivästyminen) tai epävarmuus tulevista töistä (esimerkiksi vuosisuunnitelmassa ei oman vastuualueen kohdalla ole mitään suunnitteilla) olivat tällaisia tilanteita (ks. Isopahkala-Bouret 2005, 191-201).

Asiantuntijuuden tarkastelu kokemuksellisena ilmiönä tarjoaa aikuiskasvatustieteen tutkijoille ja työelämän kehittäjille uudenlaisen lähestymistavan asiantuntijayhteisöjen toimintaan. Kokemuksellisuuden kautta saadaan mukaan toimijoiden näkökulma ja voidaan tutkia sitä, mitä osallistuminen asiantuntijayhteisöihin edellyttää, millaisin ehdoin se mahdollistuu ja miltä se tuntuu. Kokemuslähtöinen tarkastelu mahdollistaa myös intressiristiriitojen ja valtakysymysten tarkastelun mikrotasolla. Se mahdollistaa myös asiantuntijuuteen liittyvän itsensä oikeanlaisena esittämisen tutkimisen. Asiantuntijuuden "performointi” ei ole vain muille (työnantajalle, asiakkaille) tietynlaisena esiintymistä, vaan kysymys on myös omille kokemuksille annettavien merkitysten muokkaamisesta ja mahduttamisesta kulttuurisesti hyväksyttyihin raameihin.

Kokemuksellisen asiantuntijuuden mallia voidaan soveltaa jatkotutkimuksissa erilaisissa työelämän konteksteissa, kuten tässä tutkimuksessa tehtiin. Se soveltunee myös korkeakoulukonteksteissa tapahtuvaan kehittyvän asiantuntijuuden tarkasteluun. Malli lisää ymmärrystä asiantuntijuuden kokemuksellisista reunaehdoista ja antaa täten suuntaviivoja siihen, kuinka kehittää asiantuntijatyötä toimijoiden ehdoilla. Lisäksi mallilla on annettavaa työnohjauksellisena välineenä. Se auttaa jäsentämään oman asiantuntijuuden kokemuksellista rakentumista ja mahdollistaa omaan asiantuntijamaiseen toimintatapaan kohdistuvien haastavien tilanteiden tunnistamisen ja purkamiseen.

\section{Lähteet}

Ashforth, B. (2001). Role transitions in organizational life: an identity-based perspective. Lawrence Erlbaum Associates Publishers.

Bereiter, C. \& Scardamalia, M. (1993). Surpassing ourselves. An inquiry into the nature and implications of expertise. Open Court Publishing Company.

Eräsaari, R. (2002). Avoimen asiantuntijuuden analytiikka. Teoksessa Pirttilä I. \& Eriksson S. (toim.) Asiantuntijoiden areenat. SoPhi, 21-38.

Eräsaari, R. (2003). Open-context expertise. Teoksessa Bammé, A., Getzinger G. \& Wieser B. (toim.) Yearbook of the Institute for Advanced Studies on Science, Technology and Society. Profil Verlag, 31-65.

Fenwick, T. (2004). Towards a critical HRD in theory and practice. Adult Education Quarterly, Vol. 54 (3), 193-209.

Filander, K. (2000). Kehittämistyö murroksessa. Sitoutuminen, sopeutuminen ja vastarinta julkisella sektorilla 1990-luvulla. Tampereen yliopisto.

Friman, M. (2004). Ammatillisen asiantuntijan etiikka ammattikorkeakoulutuksessa. Jyväskylän yliopisto.

Gee, J. P. (2005, 2nd ed.) An introduction to discourse analysis. Theory and method. Routledge.

Glaser, R. \& Chi, M. (toim.) (1998). The nature of expertise. Lawrence, Erlbaum.

Goodson, I. \& Sikes, P. (2001). Life history research in educational settings: learning from lives. Open University Press.

Hakkarainen, K., Palonen, T. \& Paavola, S. (2002). Kolme näkökulmaa asiantuntijuuden tutkimiseen. Psykologia. Vol. 37 (6), 448-646.

Hakkarainen, K. Palonen, T, Paavola, S. \& Lehtinen, E. (2004). Networked expertise: Professional and educational perspectives. Elsevier.

Hytönen, T. (2002). Exploring the practice of Human Resource Development as a field of professional expertise. Jyväskylän yliopisto.

Isopahkala-Bouret, U. (2005). Joy and struggle for renewal. A narrative inquiry into expertise in job transition. Helsinki University Press.

Kotila, H. (2000). Ammattikorkeakoulun opiskelijoiden kokemuksia opetussuunnitelmasta. 
Helsingin yliopisto.

Launis, K. \& Engeström, Y. (1999). Asiantuntijuus muuttuvassa työtoiminnassa. Teoksessa Eteläpelto, A. \& Tynjälä, P. (toim.) Oppiminen ja asiantuntijuus. WSOY, 64-81.

Lave, J. \& Wenger, E. (1991). Situated learning. Legitimate peripheral participation. Cambridge University Press.

Mishler, E. G. (1986). Research interviewing: context and narrative. Harvard University Press.

Norris, N. (1991). The trouble with competence. Cambridge Journal of Education. Vol. 21 (3), 331-342.

Parvinen, J. (2006). Kollektiivinen tiedonrakentaminen asiantuntijatyössä. Teoksessa Parvinen, J. (toim.) Kollektiivinen asiantuntijuus. Tampereen yliopistopaino, 155-187.

Reunanen, J. (1996). Asiantuntijavalta. Asiantuntijavalmistelu ministeriössä ja asiantuntijavallan idean kehittely vanhaeurooppalaisen filosofian perustalta. Hallinnon kehittämiskeskus. Yliopistopaino.
Riessman, C. K. (1993). Narrative analysis. Sage.

Riessman, C. K. (2008). Narrative methods for human sciences. Sage.

Ruohotie, P. (2000). Conative constructs in learning. Teoksessa Pintrich, P. \& Ruohotie, P. (toim.) Conative constructs and self-regulated learning. Research Center for Vocational Education, 1-30.

Schön, D. (1986). The reflective practitioner. How professionals think in action. Maurice Temple Smith Ltd.

Tynjälä, P. (1999). Towards expert knowledge? A comparison between a constructivist and a traditional learning environment in the university. International Journal of Educational Research. Vol. 31 (5), 357-442.

Tynjälä, P. (2004). Asiantuntijuus ja työkulttuurit opettajan ammatissa. Kasvatus. Vol. 35 (2), 174-190.

Artikkeli saapui toimitukseen 21.11.2007. Se hyväksyttiin julkaistava toimituskunnan kokouksessa 10.3.2008. 